\title{
Does the Digital Marketing Capability of Indonesian Banks Align with Digital Leadership and Technology Capabilities on Company Performance?
}

\author{
Banon Amelda ${ }^{1 *}$, Firdaus Alamsjah ${ }^{2}$, and Elidjen ${ }^{3}$ \\ ${ }^{1}$ Management Department, BINUS Business School Doctor of Research Management, \\ Bina Nusantara University \\ ${ }^{1}$ Accounting Department, Faculty of Economics \& Communication, Bina Nusantara University \\ ${ }^{2}$ Industrial Engineering Department, Faculty of Engineering, Bina Nusantara University \\ ${ }^{3}$ Management Department, BINUS Business School Undergraduate Program, \\ Bina Nusantara University \\ Jakarta 11480, Indonesia \\ Email: ${ }^{1}$ banon.amelda@binus.ac.id, ${ }^{2}$ alamsjah@binus.edu, ${ }^{3}$ Elidjen@ binus.edu
}

\begin{abstract}
Digital transformation is more than just providing online and mobile banking services. The banking and finance industry needs to innovate by combining digital technology with customer interactions. In this case, these new technology findings should make it easier and more convenient for users to access banking services. However, to understand the relationship between resources (capabilities) and performance, the empirical research is still very limited and rare to explain why some firms successfully use their capabilities while others do not. The aim of the research is to answer whether digital technology, digital leadership, and digital marketing have a significant influence on company performance. The research is a quantitative study using a survey method by distributing questionnaires to employees and leaders in banks. It obtains 100 respondents. The analytical method is the Structural Equation Model (SEM) approach using the Smart Partial Least Square (PLS) statistical software. There are several obtained results. First, digital technology capabilities have insignificant effect on company performance. Second, digital leadership capability positively affects digital technology capability and digital marketing capability. Third, digital marketing capability has a positive effect on company performance. Finally, digital leadership capability only has a positive effect on company performance after being mediated by digital marketing capabilities. However, the effect is not significant if it is mediated by digital technology capabilities.
\end{abstract}

Index Terms-Digital Marketing Capability, Digital Leadership Capability, Digital Technology Capability,

Received: Aug. 31, 2020; received in revised form: Nov. 20, 2020; accepted: Nov. 23, 2020; available online: March 05, 2021. *Corresponding Author
Company Performance, Indonesian Banks

\section{INTRODUCTION}

$\mathbf{T}$ HE current technological developments have influenced the mindset of the world community, including Indonesia, towards technology that is practical, efficient, and economical. It, of course, brings changes to the business pattern that has been happening so far. The companies must embrace transformation through digital technology to enable large businesses to gain market share, such as enhancing customer experience and engagement, streamlining operations, and creating new business models. If they do not, they will face more difficulties than their competitors who do it [1].

Digital technology has changed attitudes, behavior, expectations, ways of communication, decisionmaking processes, and others. All of these changes have transformed the way organizations carry out their operations and functions [2]. Digital transformation is not an option for organizations. On the contrary, it is a must to maintain competitiveness in the market [3]. However, digital transformation is more than just providing online and mobile banking services. The banking and finance industry needs to innovate by combining digital technology with customer interactions. In this case, these new technology findings should make it easier and more convenient for users to access banking services. One of them is digital 
Cite this article as: B. Amelda, F. Alamsjah, and Elidjen, "Does the Digital Marketing Capability of Indonesian Banks Align with Digital Leadership and Technology Capabilities on Company Performance?”, CommIT (Communication \& Information Technology) Journal 15(1), 9-17, 2021.

banking. It describes a virtual process that supports all of the services.

FinTech is an example of digital transformation in finance. According to [4], one-third of customers in the world have used two or more FinTech services. Based on PwC's 11 ${ }^{\text {th }}$ Anniversary Digital IQ Survey conducted in 2018 in 60 countries with 2,268 respondents, digital banking services became a particular concern. Moreover, according to Indonesian bankers' assessment, conventional bank branches, cellular channels, and the Internet still received the highest scores from respondents based on the customer experience of $70 \%, 64 \%$, and $56 \%$, respectively [5]. After that, digital branches and e-money followed with a value of $24 \%$ each. Meanwhile, the 2019 Morgan Stanley Survey revealed that the growth of digital transactions using financial technology services reached 55\%, surpassing the increase in the use of services belonging to e-commerce $(47 \%)$, banks $(41 \%)$, cash $(35 \%)$, and cellular providers $(33 \%)$ [6].

In the context of digital marketing, the capabilities of the Internet can adapt to new needs. For example, there are products with the introduction of shared designs with customers, prices with a higher level of transparency, places with the creation of new ways to reach customers, and promotion [7]. The previous research finds that digital marketing methods allow the banking sector to reach unreached or underbanked customers and empower it to interact with the audience they wish to target [8]. Similarly, along with their high digital expectations, customers also want to see online content that matches what they are looking for in the banking sector [9].

Digital technology strongly supports the interests of customers and businesses. At the same time, it helps to drive sales and increase efficiency by reducing costs. Moreover, quality information can be transferred through digital technology [10]. The previous research states that the digital transformation of organizations can increase revenue and create higher competitive advantages and the ability to do more with fewer resources [11]. However, there is a question of whether the digital marketing capability in the bank is in line with digital leadership and technology performance.

In line with the previous researcher's views [11], the social network in banks is very influential on the success of the banking business in Serbia, especially in service operations and positioning in the Serbian banking sector [12]. It is similar to another previous researcher [13]. The results show that digital technology for the banking industry provides an important opportunity for banks to be better than their competitors and provide a higher service level to customers. Then, previous research measures the changes in efficiency in Pakistan's commercial banking sector by analyzing pre- and post-digital restructuring. The research results show that there has been a significant increase in technical efficiency in the post-digital reform era [14]. Likewise, digital marketing increases competitiveness and service delivery to its customers [15].

In contrast to previous research results $[7,11,13$, 15-17], Internet banking has an insignificant effect on operating costs and bank revenues in Vietnam [18]. Likewise, digital banking services do not provide strategic advantages for deposit banks in Turkey regarding performance and financial efficiency. The banks are efficient, but digital banking services only provide strategic positions for banks in a competitive environment [19].

The success or failure of an organization in carrying out digital transformation does not only depend on the use of digital technology on one side or part. However, it needs to be supported by all other factors. Lack of preparation and organizational ability to digitize has an impact on organizational performance to be suboptimal. In other words, it does not bring benefits to organizational performance [20]. Nearly $70 \%$ of banks worldwide do not have a systematic digital strategy [14]. Lack of digital leadership is the number one problem of hindering digital business [21]. The developed upper echelons theory states that organizational output is influenced by leader decisions based on the actors' interpretations and cognition [22]. In this case, digital leadership is urgently needed. In digital leadership, the concept is created by combining leadership skills and digital capabilities to optimize the benefits of digital technology to improve business performance.

The Resource-Based Theory describes that companies must include all resources, assets, capabilities, organizational processes, company attributes, and information because these resources foster organizational success [7, 23-25]. Several researchers have concluded that the survival and growth of a company are highly dependent on how it creates new resources, develops existing ones, and protects its core competencies [26]. A company also needs to have the ability to manage and make the best use of digital technology in the innovation process because of the capability to accelerate the innovation process by integrating and mobilizing human resources and technology strengths. In the context of the relationship between digital technology and organizational performance, the evidence is found that companies are trying to exploit their full digital potential, technology orientation, and technological capabilities. As a result, their profits are higher than the average company [27]. However, other previous research shows that digital maturity is weakly and 
Cite this article as: B. Amelda, F. Alamsjah, and Elidjen, "Does the Digital Marketing Capability of Indonesian Banks Align with Digital Leadership and Technology Capabilities on Company Performance?", CommIT (Communication \& Information Technology) Journal 15(1), 9-17, 2021.

negatively related to firm operating performance [10].

Considering the intrinsic nature of banking activities in processing, managing, and using information strategies, the digital capabilities of technology become more significant for the banking and finance industry [28]. Many banks prefer to provide services using information technology-based channels and reduce dependence on branch offices [29]. Digital technology enables companies to perceive and respond to market needs easily [30]. Therefore, the research is intended to re-test this relationship and propose the first following hypothesis:

H1: Digital technology capability will have a positive and statistically significant relationship with company performance.

Digital marketing is a term used to define integrated marketing services for attracting, engaging, and converting Internet customers. It uses several channels, such as content marketing, influencer marketing, Search Engine Optimization (SEO), social media, and online advertising. These channels help companies to connect with clients and find efficient marketing programs in real-time [15].

Then, a company needs a balance between the development of competitive advantage with the ability to implement it. It is related to the company's ability to create and implement strategies to achieve organizational marketing goals [31] and increase its resources and market position [32]. The digital marketing environment requires companies to monitor changes continually and anticipate customer reactions, so there is proactive action. Combining adaptive and dynamic capabilities with resource excellence emphasizes continuous renewal for superior performance [33]. It is useful in predicting company performance in a digital marketing environment. The relationship between digital technology and marketing capabilities plays an essential role as a facilitator of company growth [34]. The second hypothesis is as follows.

H2: Digital marketing capability will have a positive relationship and statistically significant with company performance.

Leadership is the ability to lead, manage, motivate, and coordinate activities in an organization. Leaders play an important role in community life by holding disproportionate responsibility for setting goals and inspiring collective action to achieve these goals [35]. In the digital context, the transformation in strategic leadership can change the mindset of managers who are operationally oriented from trying to be too right (and often wrong) and trying to be right roughly.

Digital leadership is created by combining leadership and digital abilities to optimize the benefits of digital technology to improve business performance. The characteristics of digital leadership consist of technology leadership, digital vision, and digital execution and images [36]. Due to its digital nature, where information can be easily accessed globally, in real-time, and transparently, leadership style in the digital era has been developed. The characteristics include creativity, deep knowledge, strong network and collaboration, and loyal participation through vision [17, 37]. Meanwhile, other previous research classifies the characteristics of digital leadership into three major groups. First, it is related to digital business, such as innovative visionary, networking intelligence, digital intelligence, complexity master, digital talent scout, business intelligence, and ambidexterity. Second, it concerns a leader's social attitudes like motivating coach, role model, openness, social intelligence, diversity champion, democratic delegate, and employee-oriented and ethical leader. Third, it is general mindset characteristics, such as adaptable, agile, learning by errors, decisive, courageous, creative, self-aware, knowledge-oriented, and life-long learner [38].

Electronic marketing (e-marketing) can also moderate the relationship between marketing competencies. Even though e-marketing is most prevalent, there are several templates for managers who wish to apply the Internet, web, or related information technology to market their products and services [39]. Managers with comprehensive, actionable, and practical methodologies (E-MARKPLAN) can plan, enforce, and analyze e-marketing activities and company performance [40]. In this case, the ability of digital marketing cannot be separated from the influence of managerial policies or digital leadership capability, according to [38]. It is the basis for this research. Therefore, the following hypotheses are proposed:

H3: Digital leadership capability will have a positive and statistically significant relationship with company performance,

H4: Digital leadership capability will be related to digital technology capability positively and statistically significantly,

H5: Digital leadership capability will be related to digital marketing capability positively and statistically significantly. 
Cite this article as: B. Amelda, F. Alamsjah, and Elidjen, "Does the Digital Marketing Capability of Indonesian Banks Align with Digital Leadership and Technology Capabilities on Company Performance?”, CommIT (Communication \& Information Technology) Journal 15(1), 9-17, 2021.

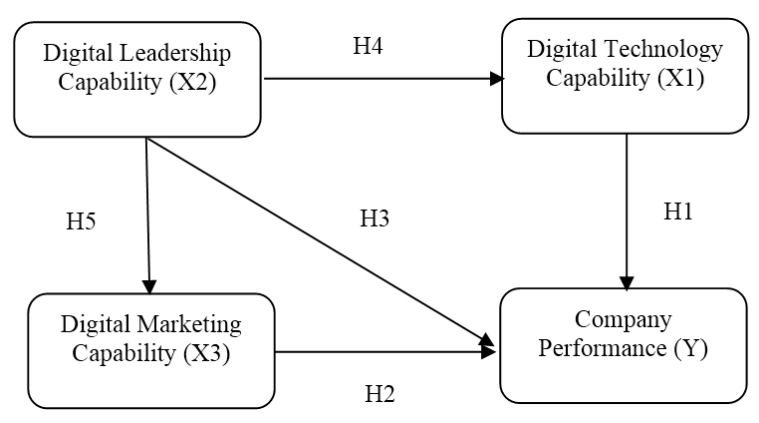

Fig. 1. Research model.

Apart from that, several empirical studies that have been carried out using RBT have now been used to understand the relationship between resources (abilities) and performance. However, it is still very limited and scarce to explain why some companies have succeeded in using their capabilities while others do not [41]. Based on the described background, the purpose of the research is to examine the effect of digital capability transformation (technology, marketing, and leadership) on company performance. It is in the context of the banking industry in Indonesia. Given the role of the market, leadership and technology in digital transformation in the banking industry have a very big role. The market holds the control for the company to compete. Meanwhile, leadership plays a role in determining a policy direction and strategic decisions for the company, and technology is the company's infrastructure in doing business. Figure 1 shows the research model.

\section{RESEARCH Method}

The research uses a quantitative approach with a survey method. The researchers distribute the questionnaires to employees and leaders in the bank. The questionnaire is divided into four groups of questions based on the observed variables. Those are company performance, digital technology capability, digital marketing capability, and digital leadership capability. The total indicators are 43. Around 23 indicators measure digital leadership capability following the characteristic criteria [38]: digital business, social attitude, and general mindset. Then, 8 indicators of digital marketing capability cover marketing innovation and market sensing. Next, 10 indicators of digital technology capability include management capability, adaptive capability, and innovation capability, and there are 2 indicators of company performance.

The sample size is determined by referring to the previous research [42] that a minimum sample size of 52 respondents is required for a model with an
TABLE I

The Results of AVerage VARiance Extracted (AVE), COMPOSITE RELIABILITY, AND CRONBACH'S AlPHA.

\begin{tabular}{crrr}
\hline Construct & AVE & Composite Reliability & Cronbach's Alpha \\
\hline X1 & 0.709 & 0.924 & 0.897 \\
X2 & 0.700 & 0.942 & 0.928 \\
X3 & 0.678 & 0.926 & 0.904 \\
Y & 0.844 & 0.915 & 0.818 \\
\hline \multicolumn{4}{c}{ (Source: Data Processing, 2020) }
\end{tabular}

endogenous construct with double-headed arrows, a significance level of $0.05,80 \%$ statistical power, and minimum R-squared $\left(R^{2}\right)$ of 0.25 . The sample amounts to 100 respondents obtained through an online questionnaire using the Linkert scale and distributed via WhatsApp. The analytical method uses the Structural Equation Model (SEM) with the Smart Partial Least Square (PLS) statistical software. It tests or manifests the relationship between variables. It can be between latent variables and indicator variables.

Respondents consist of $59.6 \%$ women and $40.4 \%$ men. The average age of respondents is over 25 years old $(75 \%)$. Most of them work in large-sized banks with more than 1,000 employees $(49.5 \%)$. They come from private banks $(85.3 \%)$, government banks $(13.8 \%)$, and joint venture banks. From their educational background, most respondents have academic degrees from bachelor $(66.4 \%)$ to master $(15.6 \%)$. The others are diploma (8.3\%) and high school (9.7\%). Respondents' positions in banks vary from employee to leader levels. Around $40.4 \%$ of respondents are in leader levels, consisting of Supervisor (13.8\%), Manager (16.5\%), Deputy Manager $(2.8 \%)$, Branch Manager (2.8\%), and Division Heads (4.5\%). The others $(59.6 \%)$ are employees. Then, the average work experience in the bank is more than five years $(80.7 \%)$.

\section{RESULTS AND DISCUSSION}

\section{A. Validity and Reliability Test}

The results of validity and reliability test are shown in Tables I-III. Table I shows the results of convergent validity and reliability tests. It can be seen that all values have met the requirements (Cronbach's alpha $>0.7$ and composite reliability $>0.7)$. The research variables have good reliability. Average Variance Extracted (AVE) is the value owned by each measured variable. If the AVE value is $<0.5$, it indicates the size of the convergent validity is not good. There are still invalid indicators, and it means that the assessment factor loading has not been completed. The AVE value in Table I is $>0.5$. It means that the measured variables have valid indicators. 
Cite this article as: B. Amelda, F. Alamsjah, and Elidjen, "Does the Digital Marketing Capability of Indonesian Banks Align with Digital Leadership and Technology Capabilities on Company Performance?", CommIT (Communication \& Information Technology) Journal 15(1), 9-17, 2021.

TABLE II

THE RESUlTS OF DisCRIMINANT VALIDITY (FORNELL \& LARCKER CRITERION).

\begin{tabular}{crrrr}
\hline & $\mathrm{X} 1$ & $\mathrm{X} 2$ & $\mathrm{X} 3$ & $\mathrm{Y}$ \\
\hline $\mathrm{X} 1$ & 0.842 & & & \\
$\mathrm{X} 2$ & 0.824 & 0.837 & & \\
$\mathrm{X} 3$ & 0.748 & 0.729 & 0.823 & \\
$\mathrm{Y}$ & 0.664 & 0.635 & 0.814 & 0.919 \\
\hline \multicolumn{5}{c}{ (Source: Data Processing, 2020) }
\end{tabular}

Then, the results of the discriminant validity using Fornell \& Larcker Criterion are shown in Table II. The correlation value between the variable and the variable itself is greater than the correlation value between the variable and other variables. It means that convergent validity can be continued by carrying out a crossloading test to obtain valid indicators.

The convergent validity value is the loading factor value on the latent variable and its indicators. The loading factor value is greater than 0.7. It means that each indicator is a valid measuring tool. From the data processing results using the Smart Partial Least Square (PLS) statistical software of the 43 research indicators, only 20 indicators have a loading factor value greater than 0.7. Only 20 indicators are valid, as shown in Table III. Meanwhile, the remaining 23 indicators are invalid because they have a loading factor value smaller than 0.7. Therefore, these invalid indicators are removed from the research data. These indicators are also not included in hypothesis testing. If they are included, the research will have weak validity. Among the invalid indicators are AC1, DG1, DG2, DG3, DG4, DG5, DG7, GM3, GM5, GM6, GM7, GM8, IC3, MC2, MC3, MC4, MI4, SC1, SA3, SA5, SA6, SA7, and SA8. Based on the results of the validity and reliability test, the used indicators can measure the variables. Then, it can proceed to the evaluation of the structure model.

\section{B. Evaluation of Structural Model (Inner Model)}

The evaluation of structural model (inner model) is presented in Tables IV-VI. Table IV shows the result of the R-squared of the model. The influence of digital technology, leadership, and marketing capabilities on company performance is 0.669 or $67 \%$. Meanwhile, the remaining effects $(33 \%)$ of the company performance are influenced by other variables that are not used in the research.

Table $\mathrm{V}$ presents the inner model test results using the bootstrapping method from SEM analysis with Smart PLS. For the hypothesis test, the research looks at the t-statistic and probability value. To test the statistical value, the researchers use an alpha of $5 \%$ and
TABLE III

The Results of ConVERGent VALIDity.

\begin{tabular}{lrr}
\hline Code & Loading Factor & Description \\
\hline AC2 $\leftarrow$ Adaptive Capability & 0.890 & Valid \\
CP1 $\leftarrow$ Company Performance & 0.938 & Valid \\
CP2 $\leftarrow$ Company Performance & 0.899 & Valid \\
DG6 $\leftarrow$ Digital Business & 0.837 & Valid \\
GM1 $\leftarrow$ General Mindset & 0.838 & Valid \\
GM2 $\leftarrow$ General Mindset & 0.815 & Valid \\
GM4 $\leftarrow$ General Mindset & 0.871 & Valid \\
IC1 $\leftarrow$ Innovation Capability & 0.845 & Valid \\
IC2 $\leftarrow$ Innovation Capability & 0.845 & Valid \\
MC1 $\leftarrow$ Management Capability & 0.808 & Valid \\
MC5 $\leftarrow$ Management Capability & 0.819 & Valid \\
MI $\leftarrow$ Market Innovation & 0.737 & Valid \\
MI $\leftarrow$ Market Innovation & 0.832 & Valid \\
MI $\leftarrow$ Market Innovation & 0.848 & Valid \\
MI5 $\leftarrow$ Market Innovation & 0.869 & Valid \\
SA1 $\leftarrow$ Social Attitude & 0.841 & Valid \\
SA2 $\leftarrow$ Social Attitude & 0.868 & Valid \\
SC2 $\leftarrow$ Market Sensing & 0.838 & Valid \\
SC3 $\leftarrow$ Market Sensing & 0.818 & Valid \\
\hline$\quad$ (Source: Data Processing, 2020)
\end{tabular}

TABLE IV

The Results of R-SQuared And Adjusted R-SQuared.

\begin{tabular}{crr}
\hline Construct & R-Squared & Adjusted R-Squared \\
\hline Y (Company Performance) & 0.669 & 0.659 \\
\hline \multicolumn{3}{c}{ (Source: Data Processing, 2020) }
\end{tabular}

a statistical value of 1.96. The criteria for accepting the hypothesis are when the t-statistic is greater than 1.96 , and the p-value is smaller than 0.05. From the test results with the bootstrapping method, it is known that the relationship between digital technology capability and digital leadership capability on company performance has a t-statistical significance value smaller than 1.96 and a p-value greater than 0.05 . It means that digital technology capability and digital leadership capability have no effect on company performance. Hence, $\mathrm{H} 1$ and $\mathrm{H} 3$ are rejected.

Meanwhile, the relationships between digital leadership capability and digital technology capability, and digital marketing capability have a positive direction with a t-statistical significance value greater than 1.96 and a p-value smaller than 0.05. It means that digital leadership capability has a positive and statistically significant influence on digital technology capability and digital marketing capability. Likewise, the relationship between digital marketing capability and company performance shows a positive direction with a t-statistical significance value greater than 1.96 and a p-value smaller than 0.05 . It implies that digital marketing capability has a positive and significant impact on company performance. Thus, H2, H4, and H5 are accepted.

The research findings show that digital technology capability (management capability, adaptive capability, 
Cite this article as: B. Amelda, F. Alamsjah, and Elidjen, "Does the Digital Marketing Capability of Indonesian Banks Align with Digital Leadership and Technology Capabilities on Company Performance?”, CommIT (Communication \& Information Technology) Journal 15(1), 9-17, 2021.

TABLE V

The Results of InNer Model Test (PATH CoefFicient).

\begin{tabular}{rrrrrr}
\hline Construct & Original Sample (O) & Sample Mean $(\mathrm{M})$ & Standard Deviation (STDEV) & T-Statistic (O/STDEV) & P-Value \\
\hline $\mathrm{X} 1 \rightarrow \mathrm{Y}$ & 0.112 & 0.106 & 0.132 & 0.848 & 0.397 \\
$\mathrm{X} 2 \rightarrow \mathrm{X} 1$ & 0.824 & 0.822 & 0.038 & 21.459 & 0.000 \\
$\mathrm{X} 2 \rightarrow \mathrm{X} 3$ & 0.729 & 0.734 & 0.049 & 14.770 & 0.000 \\
$\mathrm{X} 2 \rightarrow \mathrm{Y}$ & 0.022 & 0.016 & 0.127 & 0.174 & 0.862 \\
$\mathrm{X} 3 \rightarrow \mathrm{Y}$ & 0.714 & 0.724 & 0.123 & 0.629 & 0.000 \\
\hline \multicolumn{5}{c}{ (Source: Data Processing, 2020) }
\end{tabular}

TABLE VI

THE RESUlts OF SPECIFIC INDIRECT EFFECTS.

\begin{tabular}{crrrrr}
\hline Construct & Original Sample $(\mathrm{O})$ & Sample Mean $(\mathrm{M})$ & Standard Deviation (STDEV) & T-Statistic (O/STDEV) & P-Value \\
\hline $\mathrm{X} 2 \rightarrow \mathrm{X} 1 \rightarrow \mathrm{Y}$ & 0.092 & 0.088 & 0.109 & 0.847 & 0.398 \\
$\mathrm{X} 2 \rightarrow \mathrm{X} 3 \rightarrow \mathrm{Y}$ & 0.530 & 0.531 & 0.099 & 5.264 & 0.000 \\
\hline
\end{tabular}

and innovation capability) affects company performance. However, it does not have an effect on increasing profits or reducing costs. In terms of management capabilities, digital technology positively influences the company's strategic and business networks, which will affect company performance. In addition, digital technology capability is also adaptive. It increases the ability of employees to use digital technology. Meanwhile, the innovation in digital technology improves the services and products offered by the company. It also increases customer relationships. The effect of digital technology capability on company performance is statistically insignificant. The results strengthen the previous research [18, 19, 41].

Digital leadership capability greatly affects digital technology and marketing capabilities and company performance. It is supported by the leader's ability in digital business. A leader can develop new business models. In addition, the leader's social attitude also motivates the employees and becomes an example in carrying out digital transformation. Next, the leader's general mindset is the leader's ability to face change, coordinate with the team quickly, adapt to new business models, and develop digital transformation strategies. The firm, persuasive, and persistent attitude also plays a major role in influencing digital technology and marketing capabilities and company performance to increase profit and decrease costs. However, the effect on company performance is not more significant compared to digital technology and marketing capabilities. The results support the previous researchers' opinions [14, 21, 26, 39, 40]. In this case, the role of digital leadership is very important in encouraging the successful implementation of digital technology in the company's work processes.

Meanwhile, digital marketing capability, especially in terms of market sensing, helps companies obtain information about the market and customers to make the right decisions regarding prices, customer needs, services, and others. It has a significant effect on improving company performance, especially in profit and cost reduction. Digital marketing capability has a positive and statistically significant relationship to company performance. It means that the success of company performance is not enough to adopt digital technology into the company's work processes simply. However, the existence of digital technology needs to be supported by the ability of the organization to use technology and the literacy skills of human resources. Those, who have knowledge of technology, can use digital technology in the company more optimal. The results are in line with the previous research [20].

Table VI shows digital technology and marketing capabilities as the mediator variables. The test results using bootstrapping note that the relationship between digital leadership capabilities and company performance is mediated by digital technology capability. It shows a positive direction of relationship with a tstatistical significance value smaller than 1.96 and pvalue greater than 0.05 . It means that digital leadership capability has an indirect and insignificant effect on company performance. On the other hand, digital leadership capability has a positive and significant indirect effect on company performance mediated by digital marketing capability. It is indicated by the significant value of the relationship between digital leadership capability and company performance mediated by digital marketing capability, namely t-statistic greater than 1.96 and p-value smaller than 0.05 .

From the results, it is found that digital technology capability is not a facilitator that has an essential role in the growth of banking companies. It is indicated 
Cite this article as: B. Amelda, F. Alamsjah, and Elidjen, "Does the Digital Marketing Capability of Indonesian Banks Align with Digital Leadership and Technology Capabilities on Company Performance?", CommIT (Communication \& Information Technology) Journal 15(1), 9-17, 2021.

by the insignificant and positive influence of digital leadership capability on company performance mediated by digital technology capability. On the other hand, digital marketing capability has a vital role as a facilitator of company performance from the positive and statistically significant influence of digital leadership capability on company performance mediated by digital marketing capability. The results contradict the previous research [34].

The implication of the research is to add empirical evidence that strengthens Resource-Based Theory and views [7, 23-25]. It also provides a new perspective that the success of an organization in utilizing all resources, assets, capabilities, organizational processes, company attributes, and information depends on the type of industry and the country where the industry is located. Each industry has different characteristics, policies, visions, missions, and targets and objectives.

\section{Conclusion}

Digital transformation is more than just providing online and mobile banking services. The banking and financial industries need to innovate by integrating digital technology with customer interactions. In this case, the discovery of new technology is expected to make it easier and more comfortable for users to access banking services. However, to understand the relationship between resources (capabilities) and performance, empirical research is still very limited and it is rare to explain why some companies are successful in using their capabilities while others have not.

The research aims to answer whether digital technology, digital leadership, and digital marketing have a significant influence on company performance. The research results also have implications for the development of RBT in understanding the relationship between resource capabilities and company or organizational performance. There are several results. First, digital technology capabilities have statistically insignificant effect on company performance. Second, digital leadership capability statistically significantly and positively affects digital technology capability and digital marketing capability. Third, digital marketing capability has a positive and statistically significant effect on company performance. Finally, digital leadership capability only has a positive and statistically significant effect on company performance after being mediated by digital marketing capabilities. However, the effect is not significant if it is mediated by digital technology capabilities.

The limited number of research samples certainly affects the results. Many of the indicators are invalid.
This issue is the drawback of the research. Moreover, the research only examines bank performance in general. Hence, it is also necessary to conduct research by grouping banks based on size (Book I, Book II, Book III, and Book IV). Further research can be carried out by adding other variables such as learning organization, bank size, and its relation to the current COVID-19 condition.

\section{REFERENCES}

[1] M. Fitzgerald, N. Kruschwitz, D. Bonnet, and M. Welch, "Embracing digital technology: A new strategic imperative," MIT Sloan Management Review, vol. 55, no. 2, pp. 1-12, 2014.

[2] M. Bankewitz, C. Aberg, and C. Teuchert, "Digitalization and boards of directors: A new era of corporate governance," Business and Management Research, vol. 5, no. 2, pp. 58-69, 2016.

[3] S. J. Andriole, T. Cox, and K. M. Khin, The innovator's imperative: Rapid technology adoption for digital transformation. CRC Press, 2017.

[4] I. Sugiyama. (2017) The rapid emergence of Fintech. [Online]. Available: https://www.ey. com/en_kw/financial-services--emeia-insights/ the-rapid-emergence-of-fintech

[5] IndoTelko. (2019) Perbankan harus antisipasi disrupsi "Revolusi Industri 4.0". [Online]. Available: https://www.indotelko.com/ read/1566267782/perbank-industri-40

[6] Bisnis.com. (2019) Industri pembayaran digital: Bank dan Fintech berebut pasar? [Online]. Available: https://bit.ly/3e956rh

[7] M. A. Peteraf, "The cornerstones of competitive advantage: A resource-based view," Strategic Management Journal, vol. 14, no. 3, pp. 179-191, 1993.

[8] B. Carter, G. Brooks, F. Catalano, and B. E. Smith, Digital marketing for dummies. John Wiley \& Sons, 2007.

[9] C. W. Wanjuki, "The growth of digital marketing and its impact on customer service at Barclays Bank of Kenya, Meru Branch,” Ph.D. dissertation, Department of Business Administration, University of Nairobi, 2014.

[10] J. Wroblewski, "Digitalization and firm performance: Are digitally mature firms outperforming their peers?" Master's thesis, Department of Economics, Lund University, 2018.

[11] L. Herbert, Digital transformation: Build your organization's future for the innovation age. Bloomsbury Publishing, 2017.

[12] V. Zelenović, M. Radović, and J. Vitomir, "Banks on social networks-Example of the banking sector in Serbia," Novi Ekonomist, vol. 12, no. 24, 2018. 
Cite this article as: B. Amelda, F. Alamsjah, and Elidjen, "Does the Digital Marketing Capability of Indonesian Banks Align with Digital Leadership and Technology Capabilities on Company Performance?", CommIT (Communication \& Information Technology) Journal 15(1), 9-17, 2021.

[13] R. Maiya, "How to be a truly digital bank," Journal of Digital Banking, vol. 1, no. 4, pp. 338348, 2017.

[14] S. Mustafa and B. Mehmood, "Efficiency change in Pakistan commercial banking sector: A pre and post digital-restructuring analysis," Journal of Emerging Economies and Islamic Research, vol. 3, no. 1, pp. 30-41, 2015.

[15] W. Fute and B. J. Lyimo, "Influence of the digital marketing on performance of banking industry Tanzania: A case of Barclays Bank," Olva Academy-School of Researchers, vol. 2, no. 3, pp. 1-33, 2019.

[16] K. Peattie and L. Peters, "The marketing mix in the third age of computing," Marketing Intelligence \& Planning, vol. 15, no. 3, pp. 142-150, 1997.

[17] P. Zhu, Digital master: Debunk the myths of enterprise digital maturity. Lulu Press, Inc, 2015.

[18] V. Dinh, U. Le, and P. Le, "Measuring the impacts of Internet banking to bank performance: Evidence from Vietnam," The Journal of Internet Banking and Commerce, vol. 20, no. 2, pp. 1-14, 2015.

[19] E. Kahveci and B. Wolfs, "Digital banking impact on Turkish deposit banks performance," Banks \& Bank Systems, no. 13, pp. 48-57, 2018.

[20] P. S. Leeflang, P. C. Verhoef, P. Dahlström, and T. Freundt, "Challenges and solutions for marketing in a digital era," European Management Journal, vol. 32, no. 1, pp. 1-12, 2014.

[21] V. Mirković, J. Lukić, and V. Martin, "Reshaping banking industry through digital transformation," FINIZ 2019-Digitization and Smart Financial Reporting, pp. 31-36, 2019.

[22] D. C. Hambrick and P. A. Mason, "Upper echelons: The organization as a reflection of its top managers," Academy of Management Review, vol. 9, no. 2, pp. 193-206, 1984.

[23] J. Barney, "Firm resources and sustained competitive advantage," Journal of Management, vol. 17, no. 1, pp. 99-120, 1991.

[24] K. M. Eisenhardt and J. A. Martin, "Dynamic capabilities: What are they?" Strategic Management Journal, vol. 21, no. 10-11, pp. 1105-1121, 2000.

[25] Y. Zhuang and A. L. Lederer, "A resource-based view of electronic commerce," Information \& Management, vol. 43, no. 2, pp. 251-261, 2006.

[26] G. Ray, W. A. Muhanna, and J. B. Barney, "Information technology and the performance of the customer service process: A resource-based analysis," MIS Quarterly, vol. 29, no. 4, pp. 625-
$652,2005$.

[27] J. Bughin and N. Van Zeebroeck, "Does digital transformation pay off? Validating strategic responses to digital disruption," in Academy of Management Proceedings, vol. 2017, no. 1, 2017.

[28] O. De Bandt and E. P. Davis, "Competition, contestability and market structure in European banking sectors on the eve of EMU," Journal of Banking \& Finance, vol. 24, no. 6, pp. 10451066, 2000.

[29] D. Orlow, L. J. Radecki, and J. Wenninger, "Ongoing restructuring of retail banking," pp. 141, 1996, Federal Reserve Bank of New York Research Paper.

[30] P. Setia, P. Setia, V. Venkatesh, and S. Joglekar, "Leveraging digital technologies: How information quality leads to localized capabilities and customer service performance," MIS Quarterly, vol. 37, no. 2, pp. 565-590, 2013.

[31] D. Chaffey, "Digital business and e-commerce management strategy," in Implementation and practice (Sixth edition). Pearson, 2015.

[32] D. W. Vorhies and N. A. Morgan, "Benchmarking marketing capabilities for sustainable competitive advantage," Journal of Marketing, vol. 69, no. 1, pp. 80-94, 2005.

[33] S. D. Hunt and S. Madhavaram, "Adaptive marketing capabilities, dynamic capabilities, and renewal competences: The "outside vs. inside" and "static vs. dynamic" controversies in strategy," Industrial Marketing Management, vol. 89, pp. 129-139, 2020.

[34] P. Foroudi, S. Gupta, A. Nazarian, and M. Duda, "Digital technology and marketing management capability: Achieving growth in SMEs," Qualitative Market Research: An International Journal, vol. 20, no. 2, pp. 230-246, 2017.

[35] C. L. Hoyt and T. L. Price, "Ethical decision making and leadership: Merging social role and self-construal perspectives," Journal of Business Ethics, vol. 126, no. 4, pp. 531-539, 2015.

[36] P. Rudito and M. F. N. Sinaga, Digital mastery: Membangun kepemimpinan digital untuk memenangkan era disrupsi. Gramedia Pustaka Utama, 2017.

[37] Y. Toduk and S. Gande. (2016) What's next in Turkey? A new leadership model for connected age. [Online]. Available: https://bit.ly/2PBBWHr

[38] M. Klein, "Leadership characteristics in the era of digital transformation," Business \& Management Studies: An International Journal, vol. 8, no. 1, pp. 883-902, 2020.

[39] M. Raoofi, "Moderating role of e-marketing on 
Cite this article as: B. Amelda, F. Alamsjah, and Elidjen, "Does the Digital Marketing Capability of Indonesian Banks Align with Digital Leadership and Technology Capabilities on Company Performance?", CommIT (Communication \& Information Technology) Journal 15(1), 9-17, 2021.

the consequences of market orientation in iranian firms," Management \& Marketing-Craiova, no. 2, pp. 301-316, 2012.

[40] S. Krishnamurthy, "Introducing E-MARKPLAN: A practical methodology to plan e-marketing activities," Business Horizons, vol. 49, no. 1, pp. 51-60, 2006.

[41] Y. F. Yang, "The roles of human resources, information technology, and marketing knowledge capabilities in performance: An extension of the Resource-Based Theory perspective," Social Behavior and Personality: An International Journal, vol. 36, no. 9, pp. 1269-1282, 2008.

[42] J. F. Hair, C. M. Ringle, and M. Sarstedt, "Partial Least Squares Structural Equation Modeling: Rigorous applications, better results and higher acceptance," Long Range Planning, vol. 46, no. 1-2, pp. 1-12, 2013. 